\title{
Power of Automotive Supplier Cluster: The Case of BMW in South Carolina
}

\author{
Selcuk Karayel, Assistant Professor \\ Necmettin Erbakan University, Turkey
}

doi: 10.19044/esj.2017.v13n4p87 URL:http://dx.doi.org/10.19044/esj.2017.v13n4p87

\begin{abstract}
The phenomenon of regional industrial concentration, or agglomerations, has been studied for more than a century. Over the past couple of decades, interest has dramatically doubled both from the aspects of academics and policy makers. However, the process of making a car requires more sophisticated and complex technology and an upper level of knowledge. The collaboration is indeed an inevitable tool. The agglomeration of the automotive industry in the upper Midwest of the US is one of the most prominent and persistent industrial clusters. Historically, automotive production in the US was dominated by the big three domestic manufacturers, namely: Ford, GM, and Chrysler. However, in the last 30 years, many foreign-owned manufacturers (e.g. Honda, BMW) have opened assembly lines in the South which is far away from the automotive industry center in Michigan (Rosenbaum, 2013). These assemblers were attracted to the South due to the lower rates of unionization and lower labor costs in those states. In this paper, the researcher focus on the competitiveness of this collaboration, if there is any, by using three star analysis and the strength of foreign trade capabilities by Vollrath Analysis.
\end{abstract}

Keywords: BMW, Auto parts cluster, Location Quotient, Three Star Analysis, Vollrath Analysis

\section{Declaration of Conflicting Interest}

The author declared no potential conflicts of interest with respect to the research, authorship, and/or publication of this article.

\section{Funding}

The author received financial support from 'The Scientific and Technological Research Council of Turkey’. 


\section{Purpose}

Local areas have come to realize that collaborative regionalism (i.e. cooperation among neighboring even rival jurisdiction in the form of joint economic development policy planning and action rather than parochialism) was the best method (Jacobs, 2012).

The purpose of this paper is to provide an analysis of regional concentration patterns within Turkey Auto cluster. It also aims to make comparisons with the same industry in Spartanburg, South Carolina.

This study looked at key economic changes regarding the resulting effect on such large investments. Thus, these changes are economic and social changes. Under these titles, there were many questions that were asked: Demographic changes, supply chain, education, number of firms, and unemployment rate.

\section{Methodology}

In this research, the industry cluster data was used because this data set provides some benefits for the researchers. Among many advantages, three of them were considered to be very important. (1) Describes how industries in a region is compared to each other. (2) Identify growth trends through regional location quotient analysis. (3) Compares the foreign trade power of automobile-based industry among other industries.

However, this article tries to apprise the question on how cluster agglomeration should be measured. The analysis in this paper is based on employment data, and it basically covers three dimensions: geography (national and regional level), industry (individually such as industries or combined as cluster sectors), and regional clusters which involves the combination of geography and industry. All data were collected at National Statistics Institutes.

Regional Clusters are defined using three measures: (1) the absolute size in terms of employment; (2) the degrees of dominance in the region (a sector's share of total regional employment within the cluster sector); and (3) the degree of specialization (Gini value - Location Quotient) (size relative to expected levels given the size of the region).

An important measure to describe the process of geographical concentration is the Gini coefficient. A Gini coefficient of ' 0 ' implies that economic activity in a certain industry is spread out proportionally among a set of regions according to the size of each region. Therefore, the more geographically concentrated the industry is, the higher the Gini value. It is fair to say that clusters within advanced economies with the same mobility of factors and firms between regions should reach Gini values of above 0.3 (Solvell et al., 2008). 
Regional cluster size and degree of specialization is measured along three dimensions: absolute number of employees, degree of specialization, and degree of regional market labor dominance. Each of these three measures of cluster size, specialization, and labor market focus are classified with a 'star'. Thus, the largest and most specialized clusters receive three stars.

The first indicator, referred to as 'size', describes the region's share of total employment in a cluster category. If this value is among the top $10 \%$ of a particular cluster category, a star is awarded. The second indicator is referred to as 'dominance', and it refers to the cluster category's share of the employment in a region. If this value is among the top $10 \%$ of all clusters categories and all region, a star is awarded. The third indicator is called 'specialization' and is identical to the location quotient. This indicator measures how over-representing a cluster category is in a region is relative both to the total employment of the region and to the total employment of the cluster category. If the specialization value (location quotient - Gini value) is above 2, a star is awarded. Therefore, this roughly represents the top $10 \%$ of all cluster categories and all regions.

Besides the three star analysis, the automotive clusters about their foreign trade capabilities are evaluated by using Vollrath Analysis.

\section{Originality}

The study is introducing a new method of ranking clusters according to the three star modeling and Vollrath analysis. This method is used for auto parts cluster in Spartanburg, SC. In addition, automotive cluster, in general, is also mentioned during the explanation of autocrats cluster results.

\section{Conceptual Framework}

Subsequently, today's market circumstance is characterized by diverse customer experiences and preferences, huge discoveries in science and technology, and impact of globalization (Hsu \& Wang, 2004). Geographic concentration of firms in internationally successful industries often occurs. This is because the influence of the individual determinants in the 'diamond' and their mutual enforcement are heightened by close geographic proximity within a nation (Porter, 1990). However, these include accessing specialized pool of work force, supplier's power, severe of competition, and knowledge spillover from customers and suppliers.

The main elements of industrial cluster success can be placed under three categories: the core cluster, emerging innovation from cluster, and effects of globalization (Malcolm \& Stephen, 2010).

A century ago, the automotive value chain was almost exclusively in the hands of the car manufacturer. However, due to the complexity of 
assembling cars and the development of automobile manufacturing technology, the production of cars are now more disintegrated. Also, they are vertically distributed among wide range of suppliers. Besides, these suppliers are more specialized than before and they are manufacturing from simple components to more advanced parts by using high technology (Takeishi, 2001).

It is not realistic to depend on a sole company to accomplish the high technology alone. All that point to the fact that strategic alliances undertake a vital role for the company's competitive achievement (Cassiman et al., 2009). Subsequently, they supply appropriate complementary resources such as R\&D activities, component design, engineering, and manufacturing (Grant \& C. Baden-Fuller, 2004).

Many of the parts used by the major automobile manufacturers (referred to in this paper as assemblers) to produce cars come from a large network of suppliers. These suppliers are frequently categorized into tiers, reflecting their locations in the 'river' of production (Gassman, 2010). Thus, we categorized the tiers into three sections according to their relationship with the assembler.

The importance of the geographical proximity of suppliers to assemblers is a result of multiple features of the industry. For more than 30 years now, inventory control, whereby a part is delivered to the assembler soon before it is needed on the assembly line, has become a dominant logistic model (Klier \& Rubenstein, 2008).

Companies should develop a supply chain system to handle the uncertainty that arises from variability in demand. BMW has watched successful suppliers chain achievement in Spartanburg, SC to precede the process of final assembly (Gunasekaran et al., 2009).

According to the University of South Carolina (USC) Moore School of Business study, the "core" cluster includes 12 Original Equipment Manufacturers (OEMs). Thus, these equipment manufacturers assemble a final product in the state. Also, 309 core suppliers are mostly "Tier 1," meaning they sell directly to OEMs. More than 40 of BMW's tier 1 suppliers are located in Upstate SC. The larger cluster supplier network is composed of over 4,600 firms that include "Tier II" suppliers. Thus, these suppliers generally do not sell directly to OEMs and provide a wide range of goods and services. More than 40 suppliers provides BMW within SC with 170 total of North American suppliers, and the average distance to the Spartanburg plant is around 180 miles (Nash, 2011).

The enlargement of the BMW also attracts new second- and thirdtier auto supplier to the state. Thus, the heightened level of production presents suppliers with a sound business case to establish facilities here, rather than ship product to South Carolina (Miller, 2014). 
Furthermore, the final assembler company develops flexible manufacturing high-techniques that allow the company to establish product to order. To support this strategy, they run a lean manufacturing operation by working closely with suppliers. In addition, component and material inventories are minimized and the process cost is reduced. The close relationships and support of suppliers have allowed the companies to operate with nearly no work-in-process inventory. Even the company averages less than one day's worth of inventory and component parts stock supply. They pull parts from suppliers just as they are needed for production. Faxes or phone massages or just driving car in the same neighborhood, containing replenishment requirements are forwarded to suppliers based on actual orders. This is done such that there is no finished inventory in the stock to manage (Bowersox et al., 1999).

The key concerns in dealing with BMW includes whether national, state, and local economies would benefit from this investment; whether the means used to attract FDI actually produced a return on investment for regional economies; and moreover, whether those investments produced a measurable impact. In addition, we address these questions within a modern global context by analyzing the impact of BMW on state and local economies, companies, and consumers.

According to study by the USC's Moore School of Business, BMW has $\$ 16.6$ billion annual impact on the state and support jobs for 30,000 SC's. Moreover, the study found that for every job created at the Spartanburg plant, an additional three jobs are created somewhere else in the state. BMW attracted companies to join it as part of its suppliers system, which resulted to the employment of a lot of people. So BMW is employing about 8000 directly and about 22,000 in their supplier system right now. Thus, this is the in-state supplier system. According to SC Department office, SC ranked second in the US in automobile exports in 2013 (Buris, 2014).

A 2008 study by USC's Moore School of Business set the broad annual economic impact plant on SC at more than 8.8 billion (Woodward, 2009). However, maybe the profit of BMW investment in SC is not only evaluated by monetary terms. Also, psychological effects sometimes are much more important.

The continued success of industrial clusters is related with emerging new technologies, start-up firms, the presence of the newest features research facilities, and well equipped educational institutions which form a basis for innovation (Dearlove, 2001). Moreover, the automotive industry is known for its distinctive vertical $R \& D$ alliances between manufacturers and suppliers and the focal position of the auto OEM's play therein. Supplier's knowledge and R\&D capabilities are of significant importance to the success of auto OEMs. This is because they allow for flexible product development 
and lean production activities which allow them to reach increased economies of scale (Handfield, 1999).

Consequently, this is performed so that this supply chain system produces a final output based on individual customer requirements in a timely and cost competitive manner by leveraging global outsourcing, the application of information technology, through the standardization of components, and delayed product differentiation strategies (Gunasekaran \& Ngai, 2005).

This considers some example from different industry in order to be more clearer, but they are still related with manufacturing. Also, they emphasize the importance of the effective supply chain. In 1999, when Apple Computer was unable to fulfill orders for its new high-end line of G4 computers because of delays in chip supplies, the company experienced a devastating 14\% drop in revenue . This would not have happened if Apple had been able to address these delays and not met with them by managing suppliers and optimal production schedules. The key word in this example is 'managing supplies' which is significantly important (Gunasekaran \& Ngai, 2009). What BMW and similar auto cluster are to be close enough not to meet are similar results. Moreover, in this type of system, proximity to core supplier is important for the flexibility and reliability of supply (KPMG, 2005). More especially for the auto supplier companies, this proximity is much more important than many sectors.

Literature review shows that Marshals firstly described the industrial clusters as a special organization in economics theory. According to Marshal vision, the cluster is an agglomeration of companies that is placed in the same industrial zone and which is operating in the same industry. The Marshal model is just focusing on the economic benefits of agglomeration. These benefits include decreasing the transportation and transaction costs, access to abundant resources, a pool of qualified work force, and accessing free market information (Marshall, 1920).

However, the importance and popularity of cluster increased after Porter published his research. Porter believes that cluster works in a competitive environment to increase productivity and efficiency of the cluster and the implicitly of each member. The definition of cluster contains social relation and the transfer of knowledge between cluster members (Saxenian, 1994). On the other hand, there are some similarities and common points in both competition policy at organization or governmental level and 'cluster.' The big difference is that cluster requires an analysis of 'geographic concentration of interconnected companies and institutions in a particular field (M. Porter, 1998). 


\section{Overview of the Region}

What can organizations do to develop the resilience required to withstand major global shocks? In recent decades, wars, oil crises, talent shortages, political issues, and most recently the 2008-2009 global financial crisis, have tested the sustainability of major enterprises. Even some wellknown corporations did not survive the global financial crisis. Others had to be bailed out by their governments. At that point, the agglomeration of the related companies, financial institutions, R\&D centers, and other parties have again proved the importance of its entity in an economical environment.

Between 1900 and 1930, Detroit experienced nearly unparalleled growth for a large city, growing six-fold from a population of 305.000 to 1.837.000. There was no secret formula behind this growth. It was fueled by the concentration around Detroit due the automobile industry which, by 1929, was the largest industry in the US (Davis, 1988). The industry in Detroit went through a prolonged and severe shakeout of producers, evolving to be an oligopoly dominated by three famous Detroit - based firms; GM, Ford, and Chrysler (Klepper, 2011). However, based on this example, the researchers observe that similar success can be said for Spartanburg.

In this paper, the researcher focused on central clustering (one-hub) concept. BMW and its allies have been doing a good business for more than two decades in Spartanburg, South Carolina. BMW, which is headquartered in Munich, Germany, was founded in 1916. Today, the company employs around 96000 people at 24 production facilities in 13 countries and operates a global three premium brands: BMW, Mini, and Rolls Royce.

He luxury passenger car producer, BMW, is the sole global assembler of some of his models. That is why its entity is considerably strategic in SC. Besides, BMW exports more than 70\% of the vehicles from SC base. With this face, BMW auto cluster was named as export oriented cluster. Since its opening in 1994, BMW has accomplished incredible success in many statistics. These are briefly noted below (US Official News, 2014)

Employment has grown from 500 in 1994 to more than 7,000 in 2012. In 2011, production at BMW's South Carolina plant increased by 73 percent to 276,065 vehicles. Exports to 129 markets amounted to 192,000 vehicles worth $\$ 7.4$ billion, a 68 percent increase on $\$ 4.4$ billion in 2010 , confirming the plant as the leading U.S. automotive exporter (American International Automobile Dealers, 2012).

BMW supports 23050 jobs in the state and generates $\$ 1.2$ billion in wages/salaries. According to the Southern, BMW in SC has announced that the company is planning to enlarge their manufacturing facility by adding 800 new job and increasing their capacity from 350.000 to 450.000 units annually (http://governor.sc.gov) (Nash, 2011; Anderson, 2011). Therefore, 
this is making the Spartanburg facility to be the highest capacity in the BMW global system by the end of 2016. All this development and expanding export values causes the BMW to become the top user by cargo values as well as a major customer of the new South Carolina Inland Post in Greer.

It is obvious that the larger the investment and the greater the number of jobs created, the more the Government/State seeks to secure such mobile investments. The focal point of this statement is that local or governmental participation of this contest helps to increase the attraction to the inward investment. Dealing with SC example, the local authority supply to BMW with significant subsidies is worth $\$ 150 \mathrm{~m}$ to be located in the state (Anderson, 2014). Besides, the authority is still searching new ways to keep FDIs attraction to the region.

\begin{tabular}{|c|c|c|c|c|c|}
\hline 1994 & 2010 & 2011 & 2012 & 2013 & 2016 \\
\hline $\begin{array}{l}\text { Employment } \\
\text { has grown } \\
\text { from } 500 \\
\text { since } 1994 \text { to } \\
8000 \text { at the } \\
\text { end of } 2014 .\end{array}$ & $\begin{array}{c}2008 \text { was } \\
\text { announced and } \\
2010 \\
\text { completed new } \\
\text { investment of } \\
\$ 750 \text { million, } \\
\text { and } 1600 \text { jobs } \\
\text { were added. }\end{array}$ & $\begin{array}{c}\text { Produced } \\
276,065 \\
\text { vehicles for over } \\
130 \text { markets } \\
\text { around the } \\
\text { world } \\
\text { representing a } \\
73 \% \text { increase } \\
\text { versus } 2010 .\end{array}$ & $\begin{array}{l}\$ 900 \text { million } \\
\text { expansion and } \\
\text { adding } 300 \text { new } \\
\text { jobs. }\end{array}$ & $\begin{array}{c}\text { 297,326 } \\
\text { vehicles in } \\
2013 \text { for } 140 \\
\text { global markets. }\end{array}$ & $\begin{array}{l}\text { \$1 billion } \\
\text { investment } \\
\text { Create more } \\
800 \text { new job. }\end{array}$ \\
\hline \multirow[t]{2}{*}{$\begin{array}{l}\$ 3.7 \text { billion } \\
\text { investment }\end{array}$} & $\begin{array}{l}\text { Increase } \\
\text { production by } \\
33 \text { percent } \\
\text { from } 160,000 \\
\text { to } 240,000 \\
\text { units per year } \\
\text { by } 2012 \text {. }\end{array}$ & & $\begin{array}{l}\text { Addition of X4 } \\
\text { and the plant will } \\
\text { raise production } \\
\text { capacities up to } \\
300,000 \text { units. }\end{array}$ & $\begin{array}{l}\text { More than } 70 \\
\text { percent of the } \\
\text { vehicles } \\
\text { produced } \\
\text { (210,670) were } \\
\text { exported in } \\
2013 .\end{array}$ & $\begin{array}{c}\text { Addition of } \\
5^{\text {th }} \text { vehicle } \\
\text { platform : } \\
\text { X7. }\end{array}$ \\
\hline & & & $\begin{array}{l}\text { By the } \\
\text { end of the year, } \\
\text { the plant will } \\
\text { employ } \\
\text { nearly } 7,500 \\
\text { people at its } \\
\text { more than } \\
\text { 4-million-square- } \\
\text { foot facility. }\end{array}$ & $\begin{array}{l}\text { Being the Port } \\
\text { of Charleston's } \\
\text { top user by } \\
\text { cargo value as } \\
\text { well as a major } \\
\text { customer of } \\
\text { the new South } \\
\text { Carolina } \\
\text { Inland Port in } \\
\text { Greer. }\end{array}$ & $\begin{array}{c}\text { Productivity } \\
\text { capacity from } \\
350,000 \text { to } \\
450,000 \text { units } \\
\text { annually. }\end{array}$ \\
\hline
\end{tabular}

Since 1994, the plant has undergone four major expansions and produced 6 different BMW models and their variants (318i, Z3, Z4, X5, X6, and X3). Employment has grown from 500 in 1994 to more than 7,000 today (www.governer.sc.gov; Nash, 2011).

On the other hand, the economic impact of financial incentives has been provided to inward investors in the South, concluding that the presence 
of large firms has 'little or no impact' on regional growth (Fox \& Murray, 2004). It means that many indicators related with automobile industry in SC shows there is a significant improvement in many economic aspect. However, in general, the rank of SC is approximately the same place for 20 years.

Even some opponent aspect, the Upstate region of South Carolina witnessed dramatic economic movement with the BMW investment. Traditionally, in a manufacturing- intensive region, the region's shift into automotive production has created a stronger automotive cluster and a more diversified economy. Also, the production culture has been changed instantly. Moreover, according to Woodward and Guimarães study, the total economic impact of FDI measures the extent to which BMW provides employment and income for Spartanburg, South Carolina residents, both directly and indirectly (Woodward, 2009). One of them states that BMW's influence in upgrading the technological research capabilities of SC and BMW has been taken as a sustainable enterprise. This is with a strong commitment to environmental stewardship and community involvement.

According to Woodward, BMW has an especially large multiplier effect for two fundamental reasons: (1) its extensive regional supplier network and (2) its relatively large direct payroll, which is largely spent at local businesses.

Consequently, there are some significant examples on how some investment was founded in the same region as well. Bridgestone and Continental Tire are two distinguished Upstate FDI investment in SC. Also, within the transportation industries family, aviation giant Boeing has a significant presence in the region. In order to leverage these investments, the state provides site and infrastructure grants as well as eligibility for job credits and other economic development incentives (Cole, 2013). It shows that local authority is aware of FDI's economic effects on SC.

\section{Performance of Cluster Initiative}

During two decades of successful auto cluster in SC, many comprehensive worker training and R\&D centers opened. As soon as the strong and diversify cluster emerge with the local and global high demand, it will definitely appear to new suppliers (risk capital and supportive institutions). Furthermore, they would like to be part of this combination to get benefit (Raser, Kelly, 2010). The same happened in SC region. However, this incredible success was driven by industry collaboration cluster-based approaches, and partnerships between education and industry to capitalize on joint research and innovation. The Upstate is also the center of innovation for the South Carolina auto industry. Thus, these efforts were being led by groups such as New Carolina, the Clemson University, and South Carolina 
Automotive Council which is an initiative of the South Carolina Manufacturing Alliance (Cole, 2013). BMW supported the graduate program in automotive engineering in Clemson University in Greenville (US Official News, 2014). This is based on the fact that BMW commit themselves towards the development of innovations by using domestic facilities and work power. The Clemson University International Center for Automotive Research (CU-ICAR) is an advanced technology research campus where academia, industry, and government organizations collaborate on automotive research in Greenville, S.C. According to the CU-ICAR website, total investment has reached \$250 million. BMW and Michelin are the partners of this research center (www.cuicar.com).

The members of the auto parts cluster should be dynamic in order to submit innovative product to other cluster members, especially to BMW. This is done so that their status in the chamber can continue. One example about the importance of this placement is given by the president of Johnson Controls Automotive Experience, a global leader in automotive seating. Interiors and electronics is also one of the leading auto parts cluster member which have been offering high-quality and lighter weight components that reduces fuel consumption (Knox, 2012). This makes it possible for this company to still be in the first tier of BMW. According to Commerce Secretary, employment by the International Center for Automotive Industry in SC, when the BMW arrived in 1992, was attributed to the automotive industry. Thus, this was an equivalent of about 20.000 jobs. Since BMW's arrival, the estimated employment impact of auto cluster has grown fourfold. With the growing effect of BMW in SC economy, other contributing factors include expanded auto parts manufacturing, the rapid growth of the State's tire industry, and the role of transportation and logistics services have also dramatically increased.

Highway, rail, port, and air transportation in various combinations all play an important role in supporting the auto cluster and varied needs of its members. This is because the inward and outward movement of raw materials, intermediate and finished goods, people, as well as access to domestic and international markets are so vital for BMW auto cluster. BMW manufactured 300.000 cars in Spartanburg last year. 210.000 of them or about 70 percent were exported through port of Charleston (Buris, 2014).

\section{Power of Auto Parts Cluster}

There are many analysis methods which are most widely used in clustering literature such as Three Star Analysis, Herfindahl-Hirchman Method, Network Analysis, Diamond Analysis, and Shift Share Analysis. In this paper, the researcher utilized three star analysis because this techniques focuses on industrial agglomeration and employment values to assess the 
possibility of potential cluster. Three star analysis has been evolved by European Cluster Observatory (www.clusterobservatory.eu) which was financed by the European Commission. Although, despite many pros of this technics, there are some inevitable cons if the researcher solely use one period of the data. Therefore, the result is static and cannot give any general idea. In this paper, the researcher preferred wide data set to avoid these mistakes. Furthermore, there are three main indicators which are size, dominance, and specialization. In the literature, 'specialization' is also called 'location quotient' (LQ). LQ is a valuable way of quantifying how concentrated a particular industry, cluster, occupation, or demographic group is in a region as compared to the nation. It can reveal what makes a particular region "unique" in comparison to the national average. If we look at Figure 1 , which shows the LQ value of auto parts in the region, through the years 1998 to 2012, we can observe that Auto parts industry in Spartanburg is much more concentrated than SC and nearly 5-times more concentrated in the region than average in 2012. In addition, the Gini value is higher than 2. This proves that this region is more specialized than the national ratio. As a result, the first star is awarded according to the three star model.

Figure 1. "Automotive Parts” Location Quotient "Spartanburg vs.SC"

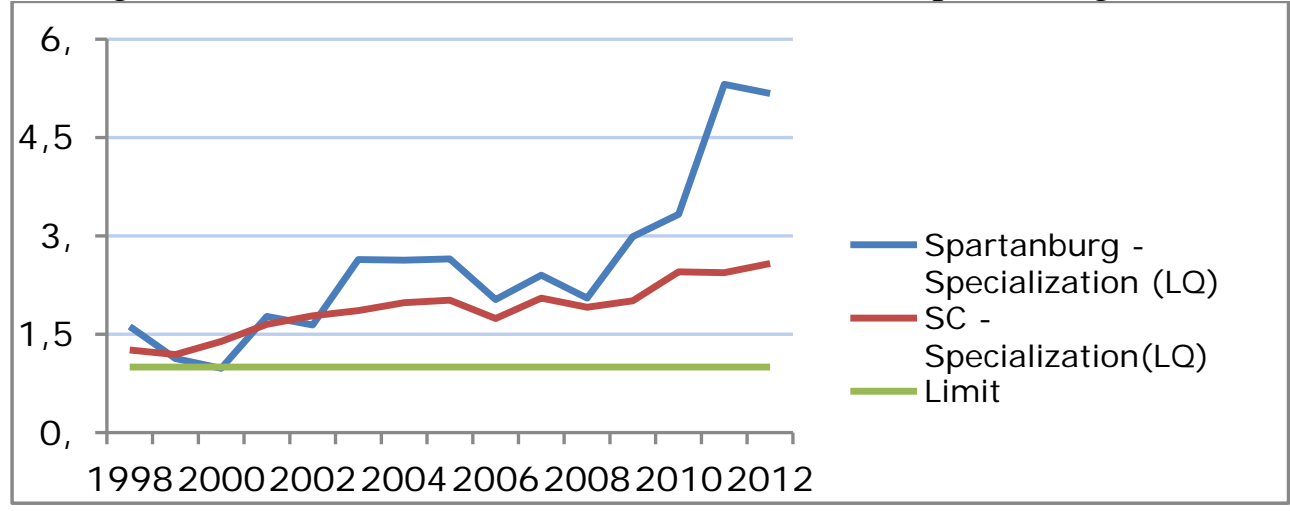

Industries with high LQ are typically export-oriented industries like automobile industry in Spartanburg, which are very important. This is because they bring money into the region, rather than simply circulate money that is already in the region. Based on the fact that automobile industry also hires very high total employment, a decline in employment or LQ proves catastrophe for the whole economy.

The second key factor in three star analysis is the dominance of the region. If we look at Figure 2, the graph shows that automotive parts dominance is below standard level. Nevertheless, automotive cluster trend between the years 1998 to 2012 is above the standard level. Also, it captured 
$7 \%$ in average. So if we look at it from an auto part side, the star is not awarded but the complimented industry earns a star.

Figure 2. Dominance_Spartanburg

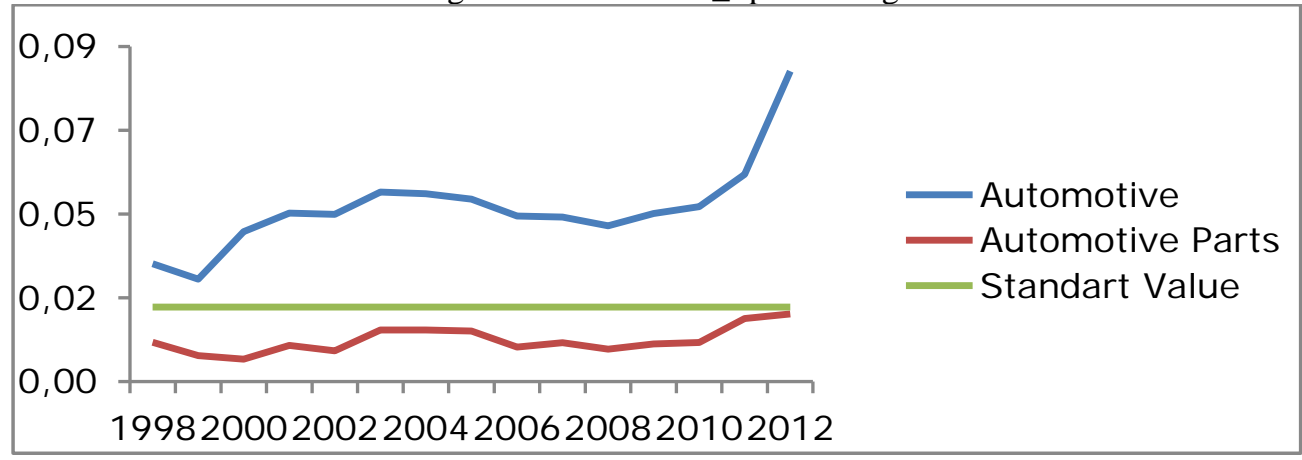

The last key factor of the model is the size of automobile and auto parts cluster. When we look at the Figure 3, both clusters are seized almost higher than $10 \%$ of the regional values. As a result, the size of the auto cluster is significantly captured by this industry. The second star is awarded.

Figure 3. Size_Spartanburg

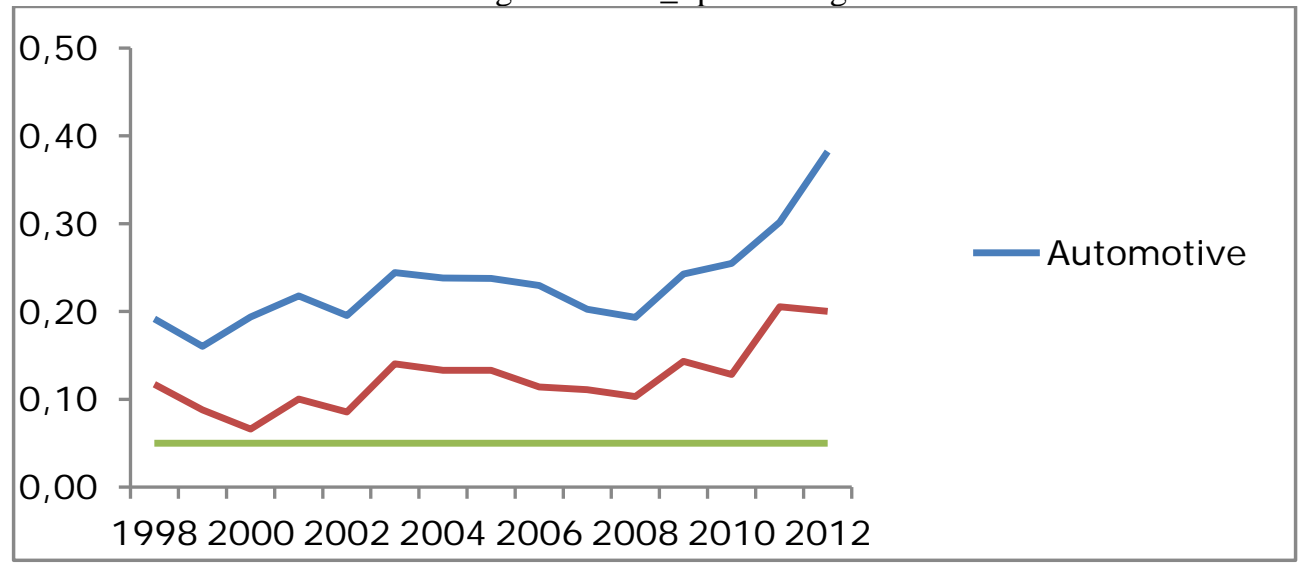

The foreign trade activities of this sector in South Carolina were evaluated by Vollrath analyses. As seen in Figure 4, SC region auto clusters are export oriented clusters. This is accomplished by using Vollrath analysis to prove the competitiveness of this sector in their region. Vollrath Analysis which measures the effectiveness of foreign trade, searches whether or not automotive and auto parts sector, is also significantly important for the region among other industries. Furthermore, Vollrath analysis for SC proves that both sectors have a competitive advantage. 
Figure 4. Foreign Trade Analysis

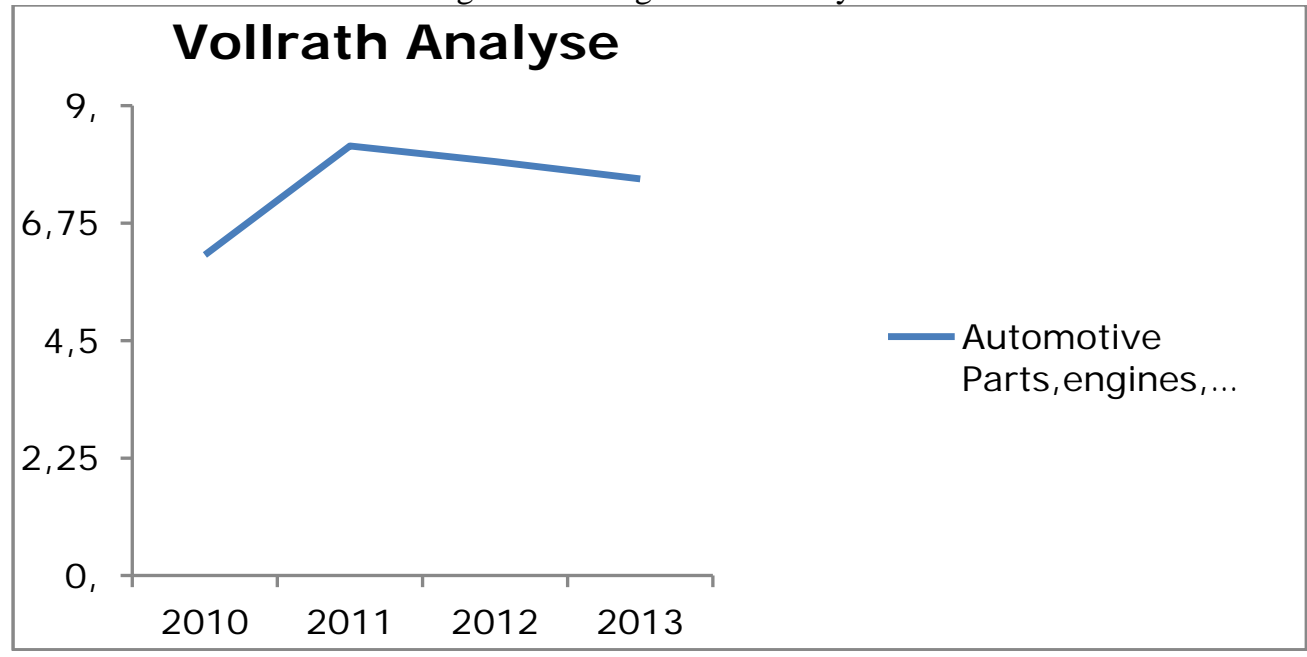

\section{Discussion and Conclusion}

BMW centered auto supplier cluster awarded two stars in the model of three star analysis. Even dominance factor is not supporting the strength of auto supplier cluster. SC based cluster gets two stars from specialization and size factors. This score gives a strong idea about the cluster's power.

Besides, according to Vollrath analysis, BMW and its suppliers establish a strong network. Additionally, the product of this cooperation has been sold to outside of US significantly.

According to SC Department of Commerce data, SC's automotive industry has quadrupled in the past two decades. The sector employs approximately 46,700 South Carolinas in more than 250 firms. This development also appeals new investments, such as Mercedes is seriously thinking to start up new facility in SC.

The changes of the cluster through time depend on the joint evolution of two dynamics that are mutually influenced: technological dynamics and regional dynamics. Faced with a changing environment, they are not always successful. Their long-term evolution depends on their viability capacities. The viability of clusters depends on the combined strength of the regional process and the technological process which are linked to the emergence conditions (Crespo, 2011).

When a region is simply a collection of a large number of assembly plants, then these investments remain mobile. Also, it can be uprooted to more attractive locations very quickly and with minimum disruption for the Multinational Corporation (McDermott, 2011). The similar results have been seen to deal with Audi in US and Honda in Turkey. Thus, in order to avoid similar effects in SC, the local authority should take precautions. 
For future research, the aim of this study is to extend it in several dimensions. By analyzing time series, it should be possible to study how automotive clusters evolve over time, and see which ones are on the rise and which ones are on the fall.

Another extension is to include performance in the study, such as measures for export activity, productivity, patents, and other output measures.

Subsequently, there will be another research topic which is internal performance. Also, four questions referred to internal performance: ability to meet deadlines; ability to meet goals; financial sustainability; and ability to attract new members and participants.

\section{References:}

1. Anderson, T. (2014), It's official: BMW announces addition of X7 to Spartanburg County plant' , Herald-Journal, Spartanburg, SC., March 28,2014

2. Bathelt, H., Taylor, M. (2002), Clusters, power and place: inequality and local growth in time- space, Geografiska Annaler, 84B: 93-109.

3. BMW Financial

Overview, https://www.bmwgroup.com/en/investor-relations/financialreports.html >, (Retrieved February 8, 2014)

4. Bobonis, G., \& Shatz, H. (2007). Agglomeration, adjustment, and state policies in the location of foreign direct investment in the United States, Review of Economics \& Statistics, 89(1), 30-43.

5. Bowersox, D.J., Stank, T.P., Daugherty, P.J. (1999) , Lean launch: Managing product introduction risk through response-based logistics, Journal of Product Innovation Management 16, 557-568.

6. Brock, G. (2009), Growth and foreign direct investment in American states, 1977-2001, Review of Urban \& Regional Development Studies, 21(2/3), 110-123.

7. Buris , (2014)' Economic giant BMW will reveal major expansion Friday', The Sate, (periodical)

8. Canaga Retna, S. (2004), The drive to move south:The growing role of the automobile industry in southern states, Spectrum, 77(1), 22-24.

9. Cassiman, B. and Guardo M. C. Di and Valentini, G. (2009), Organizing R\&D projects to profit from innovation: insights from coopetition, Long Range Planning 42(2), $216 \mathrm{e} 233$

10. Christie, L., Where to find the fattest paychecks, <http://cnnmoney.com>, (September 22, 2009).

11. Cole, D.(2013), Rewing the Economic Engine: South Carolina's Auto Cluster, NADO Research Foundation Journal . 
12. Crespo, J.(2011), How Emergence Conditions of Technological Clusters Affect Their Viability? Theoretical Perspectives on Cluster Life Cycles, European Planning Studies., Vol. 19 Issue 12, p20252046.

13. Davis, D. F. (1988), Conspicuous Production: Automobiles and Elites in Detroit, 1899-1933. Temple University Press, Philadelphia, PA.

14. Dearlove D. (2001), The Cluster Effect: Can Europe Clone Silicon Valley? Strategy+Business,(24).

15. Ferdows, K. (1997). Making the most of foreign factories. Harvard Business Review, 75 (2), 73-88.

16. Fox, W.F. and Murray, M.N. (2004). 'Do économie effects justifying the use of fiscal incentives?'. Southern Economic Journal, 77(1), 7892(p.91)

17. Gassmann, O., Zeschky, M.; Wolff, T.; Stahl, M.(2010), Crossing the Industry-Line: Breakthrough Innovation through Cross-Industry Alliances with 'Non-Suppliers', Long Range Planning, Vol. 43 Issue 5/6, p639-654,

18. Gassmann, O., Gaso, B. (2004) Insourcing creativity with listening posts in decentralized firms. Journal of Creativity and Innovation Management, 13: 3-14.

19. Grant R. M. and Baden-Fuller C. (2004), A Knowledge Accessing Theory of Strategic Alliances', Fuller, A knowledge accessing theory of strategic alliances, Journal of Management Studies 41(1), 61e84.

20. Gunasekaran, A., Ngai, Eric.W.T.(2005). Build-to-Order Supply Chain Management: A literature review and framework for development, Journal of Operations Management 23 (5), 423-451.]

21. Gunasekaran, A., Ngai, Eric W.T. (2009), Modeling and analysis of build-to-order supply chains, European Journal of Operational Research, Volume 195, Issue 2, 1, Page 319

22. Handfield R. B., G. L. Ragatz, K. J. Petersenand R. M. Monczka (1999), Involving suppliers in new product development, California Management Review42(1),

23. Hsu, H.-M., Wang, W.-P. (2004), Dynamic programming for delayed product differentiation. European Journal of Operational Research 156, 183-193.

24. International Monetary Fund.. Globalization: A brief overview. Retrieved,<http://www.imf.org/external/np/exr/ib/2008/053008.htm> (Retrieved December 1, 2008)

25. Jacobs, A. J.. (2012), Collaborative Regionalism and Foreign Direct Investment: The Case of the Southeast Automotive Core and the 
“New Domestics”. Economic Development Quarterly, Vol. 26 Issue 3, p199-219, 21p; DOI: 10.1177/0891242412453481 .p.199

26. Klepper, S.. (2011), Nano-economics, spinoffs, and the wealth of regions’, Small Business Economics. Vol. 37 Issue 2, p141-154. 14p.

27. Klier , T. H ., and James, R. (2008), Who Really Made Your Car? Restructuring and Geographic Change in the Auto Industry. W.E. Upjohn Institute.

28. Knox, J.(2012) , Johnson Controls Introduces Innovative Production Process for Lightweight Natural Door Panels, Automotive Industries. Vol. 192 Issue 6, p1.

29. KPMG (2005): "Global Location Management in the Automotive Supplier Industry," Discussion paper.

30. Malmberg, A., Maskell, P. (2006), Localized learning revisited, Growth and Change, 37: 1-18.

31. Marshall, A.(1920), Principles of Economics, 8th edition, London, Macmillan

32. Maskell, P., Malmberg, A. (1999), The competitiveness of firms and regions: 'ubiquitification' and the importance of localized learning. European Urban and Regional Studies, 6: 9-25

33. McDermott, Michael C. Luethge, D.; Byosiere, P. (2011), Automotive Investment and Foreign Subsidiary Strategy in the Southern States of the United States.Business \& Economic Journal. , Vol. 34 Issue 3/4, p10.

34. McDermott, Michael C. (2011),BMW, Spartanburg, South Carolina: drivers and processes in the international plant location decision, The Southern Business and Economic Journal, 34(1/2), 73-94. ]

35. Miller, Scott (2014) ,'BMW Expansion a boon to Supplier, GSA Business ', The Business Journal for Greenville, Spartanburg and Anderson

36. Nash, Betty J. (2011), When South Carolina Met BMW , Region Focus, Vol. 15 Issue 2, p20-22.

37. Phelps, N. A. (2008), Cluster or capture? Manufacturing foreign direct investment, external economies and agglomeration, Regional Studies, 42: 457-473.

38. Porter, M. E. (1990). The Competitive Advantage of Nations. New York: The Free Press

39. Porter, M. E. (1998), Clusters and the new economics of competition, Harvard Business Review, 76(6), pp. 77-90,

40. Raser, M.; Kelly, S. (2010), The Creation and Growth of Information Technology Communication (ICT) Industrial Clusters: The New Zealand Case, New Zealand Journal of Applied Business Research (NZJABR). Vol. 8 Issue 1, p15-26. 
41. Saxenian, A. S.( 1994), Regional Advantage: Culture and Competition in Silicon Valley and Route 128, Harvard Univ. Press, Cambridge

42. Slaughter, M. (2004), Insourcing jobs: Making the global economy work for America. < http://mba.tuck. dartmouth.edu/pages/faculty/matthew.slaughter/pdf/ insourcing_study_final.pdf > (Retrieved October 2014)

43. Slaughter, M. (2007), Let's have a real debate on globalization., < http://yaleglobal.yale. $\quad$ edu/content/let\%E2\%80\%99s-have-realdebate-globalization>, (Retrieved September,27 2014)

44. Solvell, O.; Ketels, C. and Lindqvist, G.(2008) ,Industrial specialization and regional clusters in the ten new EU member states, Competitiveness Review: An International Business Journal Vol. 18 No. $1 / 2$, pp. $104-130$

45. Takeishi A.,B. (2001), 'Inter- and intra-firm boundaries: Management of supplier involvement in automobile product development', Strategic Management Journal 22(5), $403 \mathrm{e} 433$

46. Ted Carl Rosenbaum (2013), Empirical Analyses of Automotive Supplier Plant Locations , Dissertation, UMI Number: 3571846, Yale University,

47. US Official News , 'Washington: SC Gov. Haley: BMW Announces \$1 Billion Expansion Creating 800 Jobs’, Retrieved: March 30, 2014.

48. Washington: SC Gov. Haley, BMW Announces \$1 Billion Expansion Creating $800 \quad$ Jobs Sunday, http://www.southerngovernors.org/articleview.aspx?articleid=11009\# sthash.b2tC22Ey.dpuf (Retrieved: March 30, 2014)

49. Windecker, R. (2007). Do transplants add auto jobs? No way. Automotive News, 81(6250), 14.

50. Woodward, D., Guimarães, R.(2009), BMW in South Carolina: An Update., Business \& Economic Review. Vol. 55 Issue 2, p13-21. 